\title{
A TEN YEAR REVIEW OF PERFORMANCE OF PHOTOVOLTAIC SYSTEMS
}

\author{
A. L. Rosenthal ${ }^{1}$, M. G. Thomas ${ }^{2}$, and S. J. Durand 1 \\ ISouthwest Technology Development Institutc, Las Cruces, NM \\ ${ }^{2}$ Sandia National Laboratories, Albuquerque, NM
}

\section{ABSTRACT}

This paper presents data compiled by the Photovoltaic Design Assistance Center at Sandia National Laboratories from more than cighty ficld lests performed at over thitly-five photovoltaic systems in the United States during the last ten years. Tho recorded performance histories, failure rates, and degradation of post-Block IV modules and balance-of-system (BOS) components are described in detail.

\section{INTRODUCTION}

The Photovoltaic Design Assistence Center (DAC) at Sandia National Laboralories (SNL) has been restonsible for the devolopmen and nainlenance of a comprehensive database on the performance of pliolovoltaic systems for the U.S. Department of Encrgy during the past ten years. This work has addresscd the critical issues of long-tcrm module and system rcliability, performance degradation and its mechanisms, and related maintenance topics. The DAC and the Southwest Technology Development Institule (TDI) have performed site visits to over thirty-five PV tystems located in thirlecn states, Washingion DC, Bermuda, and Puerto Kico. The installation dates for the systems testod range from 1979 to 1992 . Installed system ratings rango from 0.1 to $1180 \mathrm{~kW}$. Multiple visits were mado to many of the sites, thus providing valuable measurements of changes in systent performance with tinse.

The thirly-five PV systems evaluated for the system performance database represent a wide range of system designs, PV tcchnologics, hardwarc and manufacturers. Technologics include ringle-crybtal, amorphous, polycrystalline, and ribbon silicon modulcs. Arrays with fixed-orientation mounting as well as single and dusl-axis tracking woro tosted. All of the major manufaclurers of PV modules and power conditioning systems (PCSs) are represcntod. The sites are dispersed geographically.

\section{IIYALUATION METHODOLOGY}

At least one site visit was made to each systcm. During each site visit, the following field activitics were porformed:

- Observation of the physical state of the system noting broken or damaged modules, failed structural components, shading of the array, or any hardware failure such as nonfunclioning tracking devices:

- Inspeclion of the electrical circultry and components noling improper installation, corrosion, failures, cvidence of fire. or PCS problems;

- Testing to ldentify and mark non-producing modules, failed bypass diodes, or improper wiring connections; and

- Elcctrical testing at the array, subarray, string, block, and moslule jevel (as appropriate) using portable current-voliage (1.V) curve tracing equipment.

- When rossiblo, maintenance records and other performance data collected by site operators were iniegrated into the dats basc.
From the moasurements and observation medo during field terts, siatistics for the following were complled bail of nonproducing modules, shattered modules, failed balance-of bystem (BOS) components, wiring failures, and accuracy of system de ratings.

Simple repairs were made during the site visjts. Recommendations for system maistenance also were provided to the operators of the systems following complation of tie site visit. A detailed trip report for each site visit was prepared and is kept on file at TDI.

\section{GENRRAL, RESULTS}

Some early generation PV modules exhibited serious reliability problems. Test results from approximately 20,000 pre-Block $V$ modules are includod in the DAC system performance database. Aboul ono half of these were found to have been non-producing at the time of testing. Figure I provides a breakdown of the findings from field tesis of arrays with pre-Block $V$ modules. Of the over 10,000 non-producing modules that were found, approximately $90 \%$ had expcrienced some form of module failure (1). Within this paper, a PV module is defined as having failed when two critcria are mel: 1) its power output has fallen to less than half of its originnl rating: and 2) it can not be repajred in the ficld.

Pre-Block $V$ modules failed for a varicly of reasons. Somc of the most common reasons for failure of pre-Block $V$ modulcs wero: breakdown of the encapsulation material, hot spot formation from inadequate or lack of bypass diode protection, cell-interconnect ribbon failures and, the frequent use of experimental designs and materials during this early phase in the development of PV techinology.

The implementation of the Block Y modulc qualification test specificalions (2) in the early and mid-cighties brought much improved module reliability to fielded sysiemk. Figurc 2 presents the distribution of failure modes of non-producing modules found in the Block V module arrays tested. In contrast to carlier generation modules, the Failure rate for Block $V$ modules was less than $1.3 \%$ of those iested. Overall, $6.5 \%$ of the modules testud were found to be non-producing, but these werc generally the result of faitures of components other than the modules thamselves.

Failures of BOS compronents such as switches, fuses, blocking diodes, surge prolectors, and dc contaclors were responsible for $54 \%$ of the non-producing modules that werc found. A single BOS failure can affecl a large number of modules. An open fuse, for examiple, can lake an cntirc suring off-line.

All papers must include the following This work performed at Sandia National Laboratories is supported by the U.S. Department of Energy under contract DE-ACO4 - 76DP00789. 


\section{DISCLAIMER}

Portions of this document may be illegible electronic image products. Images are produced from the best available original document. 


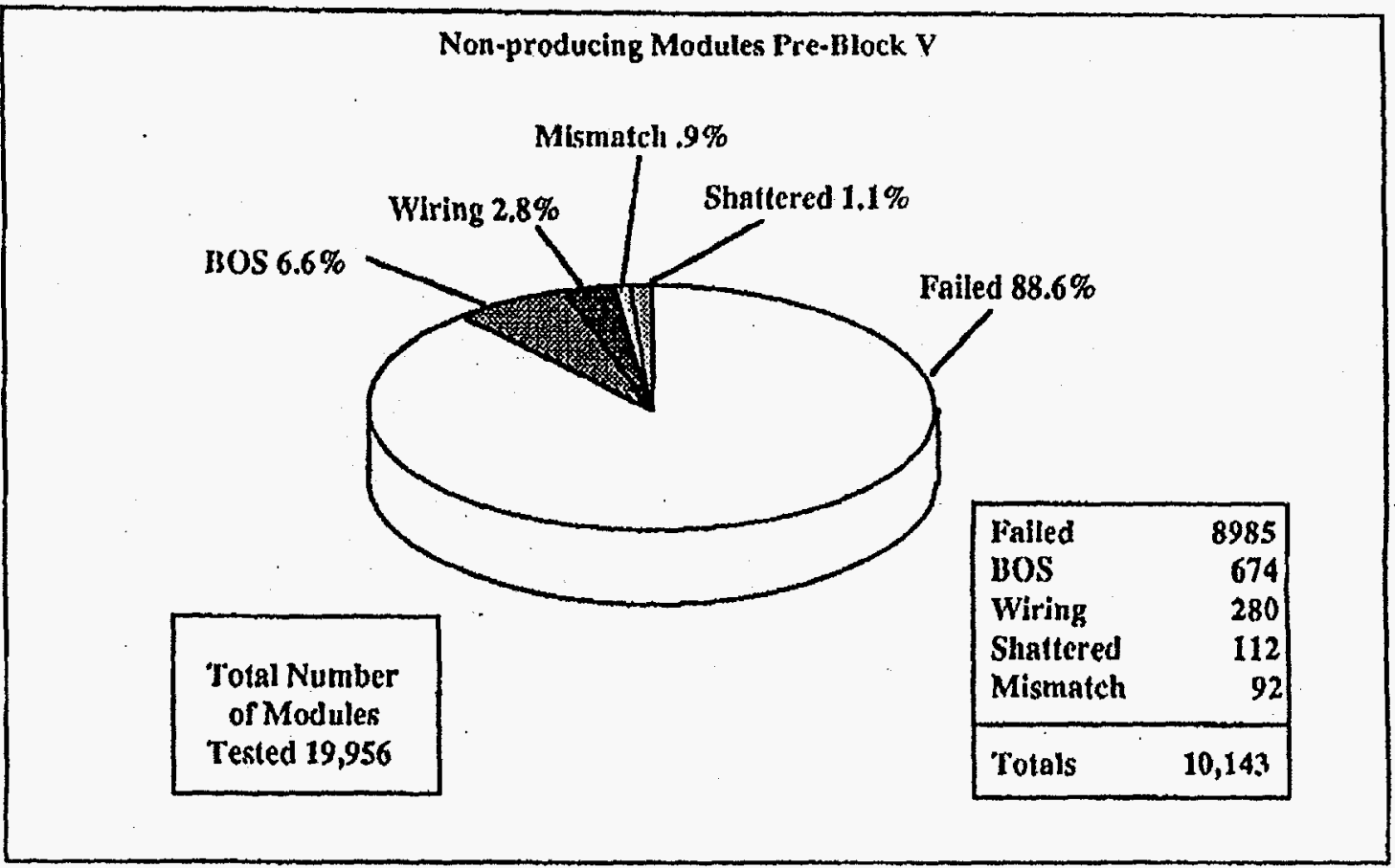

Figure 1. Non-Producing Modiules Pre-Block V

Wiring problems due to failure of the matal ribbons used in laminate/bus bar construction or within the cannectors of module junction boxes were responsible for $7 \%$ of the nonproducing modules that were found. Each module wiring problem not only affects the single module directly involved, but often results in a condition of severe mismatch for the other modulcs wircd in the same parallel block. When one module in a parallel block fails or becomes non-producing due to a witing problem, the other modules in the block can become bypassod as a result. In this way, the effect of a single module or wiring failure is ofuen multiplied by 8 or 10 in its net effect on power output. Severe mismatch was the second most common cause of non-producing Block $V$ modules, tesponsible for $38 \%$ of the total.

\section{PERIOORMANCE TRENDS}

The reliability of Block $\mathrm{V}$ motules has cnabled the collection of long-icrm performance histories for these modules and the sycloms in which they are used. Earlier, module failure rates were so great that long-ierm performance histories were unobtainable: systoms often failed or were manually disconnecled after only a year or two of operation. The PV systoms installed during the mid- and late-cighties have now becn in cuntinuous operation long enough for trends to emerge from the system performance database.

The de array ratings for several Block IV and $V$ systems have been monitored for the last seven years. Ten sets of thete data are presented in Table 1. The system ratings presented in Table 1 are those determined from ficld test incasurements for STC conditions $\left(1000 \mathrm{~W} / \mathrm{m}^{2}\right.$ irradiance, $25^{\circ} \mathrm{C}$ module (cmperaturc) and do not reflect manufacturers' nameplate values.
The dala indicale that, on average, the de performance of these systems has been declining approximately $2 \%$ per yesr. This decline in plant rating is seen to some extent in all PV module technologies: single crystal silicon; polycrystalline silicon; amorphous silicon. It is also seen in a varicty of climates.

\section{GENERAL CONCLUSIONS AND RECOMMENDATIONS}

In the late 1970's and early 1980's, the first generations of terrestrial PV systems were being implemented. For the most part, these systems were small, though a fow government sponsored systems in the tens to hundreds of kilowatts were also instalicd. For these carly generations of systems, pV modulc costs and fajlure zates were so high that the market was totally constrained by these two elements. During this time, the DOE sponsored SNLTTDI program of long-term performance monitoring and field evaluation began. The program documented the problems associated with these early sysiens. As module problems were observed, the field evaluation term would provide the module development team at JPL with samples of the failed hardware for craluation. Through this process, prevalent problerns in fielded systemis were identified and their rates of occurrence quantified, causes were evaluated, and the information was then fed back to development efforts in industry.

During the mid-1980's, a new generation of PV sysienis was being installed. These systems benefited from the lessons learned from earlicr gencrations of PV sysicms. Much of the improvement of the new systems was the result of the DOE program which developed a standard specification for modules: cven today, systems are specified with the phrase "modules must meet or exceed JPL Block V Specification". Module failure fates dropped by an order of magnitude. Long lorm field 


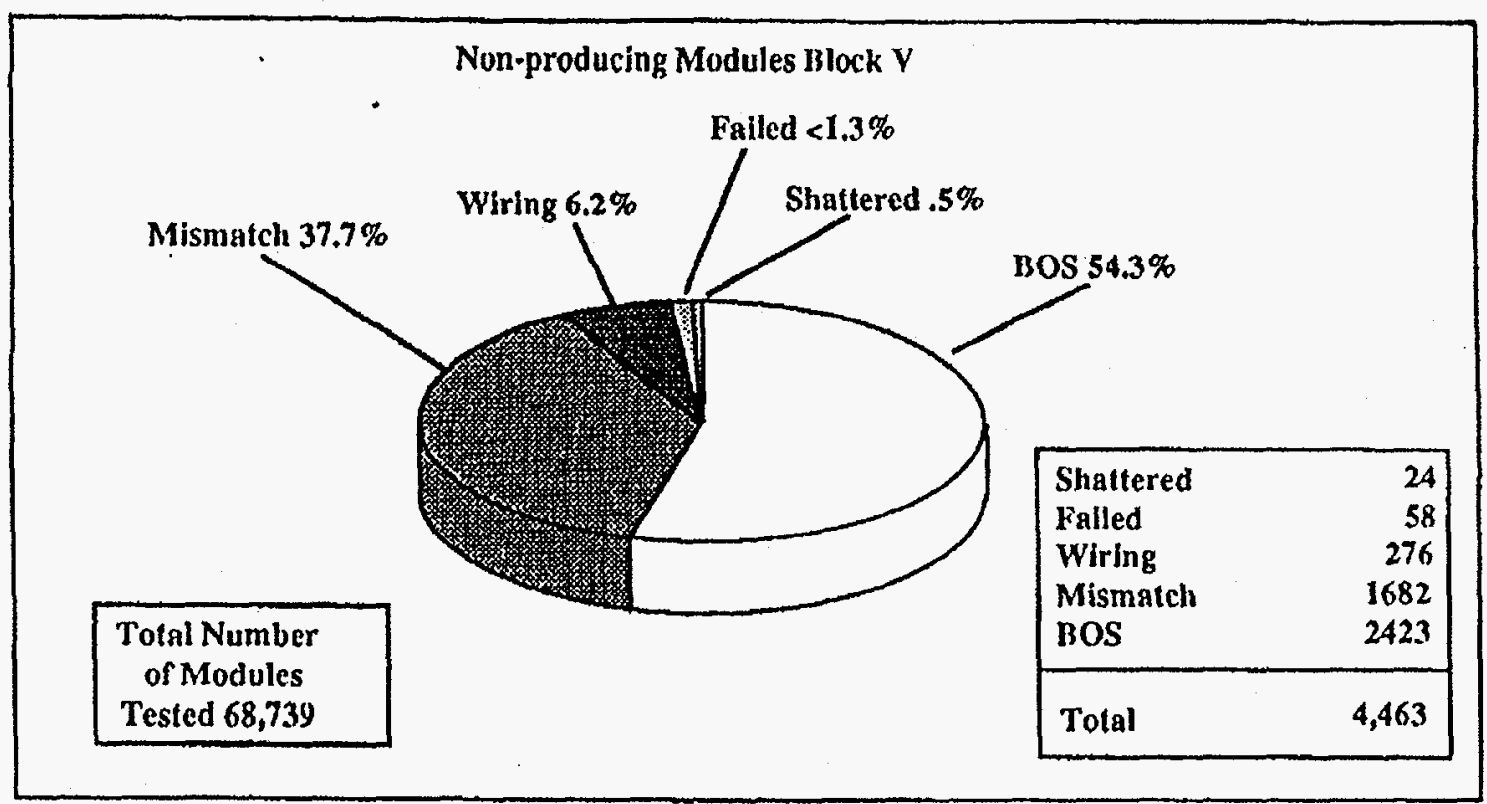

Figure 2. Non-Producing Modules Block V

cvaluation continued but al a significantly reduced rate because of the beliefs that:

- The most significant problems for PV systcms had been climinatco (module failures);

- Only nocessary and sufficient information (i.e. beller modille life) was required for validating this belief;

- The lechnology was now ready for large-scale commercialization.

Current efforts continue to improve the performance and reliability of PV systems. SNL has begun to support manufacturers directly in identifying problem areas. Through these joint efforts between industry and SNL, progress is being made to correct deficiencies found in the ficld. These efforts spán from improvements in module design to power processing cvolution. The field evaluation tean from TDI continues to evaluate and document the performance of new and existing systems installed in the ficld.

\section{ACKNOWLEDGMENTS}

The authors wish to thank John Hoffner of the City of Austin Electric Utility, and Emic Palomino of Salt River Project for helping us gain access to PV plants in their service territories, David King of Sandia National Laboratories for his work cheracterizing the spectral responses of the pyranometers used, John Wohlgemuth of Solarex, and Moncer Az.7am of Mobil Solar for their valuable revicw of ficld dala, and Jerry Anderson and Norm Beze of Siemens Solar for their assistance in the field and in revicw of the data. Support for this work was provided by Electrical Power Research Institute and $S$ andia National Laboralories.

\section{REFERENCLS}

1.S. Durand and D. Bowling, Field Experierse With Photovollaic Systems, EPRI Report, to be published, June 1993.

2.R. Ross and M. Smokler, Flat Plate Solar Array Project Final Repont, Volume VI, JPL Publication 86.31, October, 1986.

Taule 1

System $1985 \quad 1986 \quad 1987 \quad$ (kiloWatts)

\begin{tabular}{|c|c|c|c|c|c|c|c|c|c|}
\hline System & 1985 & 1986 & 1987 & 1988 & 1989 & 1990 & 1991 & 1992 & $\begin{array}{c}\text { Degradation } \\
\text { Per Year }\end{array}$ \\
\hline AUSTIN PV300 & & & 288 & 274 & 267 & 268 & & & $1.7 \%$ \\
\hline FOND DU LAC & & & & 1.7 & 1.6 & & & & $1.6 \%$ \\
\hline GEORGETOWN & 270 & & & 210 & & & & & $6.8 \%$ \\
\hline JOHN LONG & & & 181 & & 171 & & & 161 & $2.3 \%$ \\
\hline NEWMAN PS & 16.9 & & & 15.8 & & 13.8 & & & $3,9 \%$ \\
\hline SMUD PVI & 1050 & 990 & & & 947 & & & & $2.1 \%$ \\
\hline SMUD PV2 & & 988 & 926 & & 931 & & & & $1.8 \%$ \\
\hline WPEL MUNI & & 2.1 & 2.0 & & 1.9 & & & & $1.9 \%$ \\
\hline WP\&L RES & & 2.0 & & 1.9 & 1.8 & 1.8 & & 1.8 & $1.5 \%$ \\
\hline WI'\&L SOC & & & 1.8 & 1.8 & 1.6 & & & & $4.7 \%$ \\
\hline
\end{tabular}

*Accuracy of the data is within $\pm 2 \%$

\section{DISCLAIMER}

This report was prepared as an account of work sponsored by an agency of the United States Government. Neither the United States Government nor any agency thereof, nor any of their employees, makes any warranty, express or implied, or assumes any legal liability or responsibility for the accuracy, completeness, or usefulness of any information, apparatus, product, or process disclosed, or represents that its use would not infringe privately owned rights. Reference herein to any specific commercial product, process, or service by trade name, trademark, manufacturer, or otherwise does not necessarily constitute or imply its endorsement, recommendation, or favoring by the United States Government or any agency thereof. The views and opinions of authors expressed herein do not necessarily state or reflect those of the United States Government or any agency thereof. 